УДК 621.315 .1

\title{
PHASE STRUCTURE INFLUENCE ESTIMATION OF THE EXTRA HIGH VOLTAGE LINE ON ABNORMAL RESONANCE OVERVOLTAGES
}

\author{
V.V. Kuchanskyi \\ Institute of Electrodynamics of the National Academy of Sciences of Ukraine, \\ Peremohy, 56, Kyiv, 03057, Ukraine \\ e-mail: kuchanskiyvladislav@gmail.com
}

\begin{abstract}
Abnormal nonsinusoidal modes are characterized by the appearance of higher harmonics of current and voltage. The distortion of the voltage shape curve in this case is due to the nonlinearity of the magnetization shunts of noloaded autotransformer. In recent years, great attention in the study of electric networks modes has been given to fluctuations in circles with steel. The reason for this is the appearance of complex phenomena on the transmission lines of the extrahigh voltage (EHV), such as resonances at frequencies different from the main. In this paper, the attention is paid to the occurrence of overvoltages on even harmonic components caused by the connection of unloaded autotransformer.The work takes into account the degree of influence splitting step of wires and the geometrical distance between phases on the values of abnormal resonance overvoltages in non-sinusoidal operating modes of extra-high voltage power lines. An unloaded autotransformer is the source of even harmonic components, since the operating point is situated on the nonlinear part of the magnetization characteristic. A simulation model was developed to check the possible occurrence of overvoltages in the non-sinusoidal mode. Numerical modeling of electromagnetic commutation processes on the simulation model was used to identify the factors that have the greatest impact on the occurrence of overvoltages, primarily the design features of the power transmission line. The critical values of the line parameters in which the overvoltage rises to the maximum value are found. References 10, figures 5.
\end{abstract}

Key words: extra-high voltage power lines, abnormal resonance overvoltages, imitation simulation, nonsinusoidal mode, unloaded autotransformer.

The general characteristics of the problem. Trends of modern electricity grid point to the growing role of extra high voltage transmission lines as backbone and intersystem. It should be noted that the study for this lines must be done especially precisely, particularly with regard to the impact of sources of distortion. This is due to the lack of practical operational reserve insulation, designed for extreme values, as a reserve for extra high voltage lines is expensive $[6,8,9]$. Thus, analysis of the possibility of overvoltages in power lines should be implemented not only in normal modes but also for abnormal non-sinusoidal modes.

Non-sinusoidal modes are characterized by the appearance of higher harmonics of current and voltage $[1-4,6,9,10]$. The distortions of voltage and current waveforms in the case of nonsinusoidal modes appear due to nonlinearity of the magnetization shunts of unloaded autotransformer. In recent years, much attention in studies is paid to electric-mode networks with fluctuations in the circles with steel elements with non-linear characteristic. This is the reason why occurrence of resonance overvoltages at frequencies that differ from the main is a complex phenomenon $[5,6,8]$.

The main direction of previous studies was focused on the development and application of mathematical models in order to obtain quantitative results for practical use $[7,9]$. They have not found the exact cause of overvoltages in the higher harmonic components, although cases of this type are known for a long time. From these results is unclear and unknown, themselves or switching modes lead to overvoltages at the higher harmonic. An investigation in area of overvoltages was performed with great simplification, because this type of overvoltages depends on many factors. Therefore, these studies are considered as comprehensive impossible.

It should be noted that the process of the even harmonics overvoltages are generally known, but the values of the characteristics depends on many factors of abnormal mode. It is therefore necessary to develop methods for identifying key factors which most of all influence on necessary and sufficient conditions for overvoltages during the design and operation of EHV lines.

The aim of the article. The main purpose of the study was to analyze the factors that lead to the appearance of abnormal conditions in the transmission lines of extra-high voltage, which are 
accompanied by overvoltages at higher harmonic components.

Influence of the phase design overhead line on the abnormal resonant overvoltage. It is known studies of the effect of changing the factors on the occurrence of overvoltages on higher harmonics $[6,8,10]$. The main goal of these studies is the use of advanced modeling techniques, such as artificial neural networks and wavelet transforms to detect, individually and in combination, the parameters of equipment and mode of electrical network affect the characteristics of overvoltages. Such an approach made it possible to eliminate some of the most important factors that lead to overvoltages on the even harmonics.

For example, a typical geometry of $750 \mathrm{kV}$ transmission line is shown on Fig. 1, where distances are shown in meters. The construction of the wire are $5 \times \mathrm{xAS}-400$, the lightning protection wires are made by the AS-70, the placement of wires in the split phase at the tops of the pentagon with the base of $60 \mathrm{~cm}$. The radius of the wire in the phase is $1,45 \mathrm{~cm}$, the cable- $0,57 \mathrm{~cm}$, the active resistance of the phase wire is $0,020 \mathrm{Ohm} / \mathrm{km}$, lightning protection wire is $0,45 \mathrm{Ohm} / \mathrm{km}$.

An abnormal increase of the voltage occurs at certain parameters of the transmission lines, when there are necessary conditions for the resonance overvoltages. For their definition, we use heuristic formulas [2].

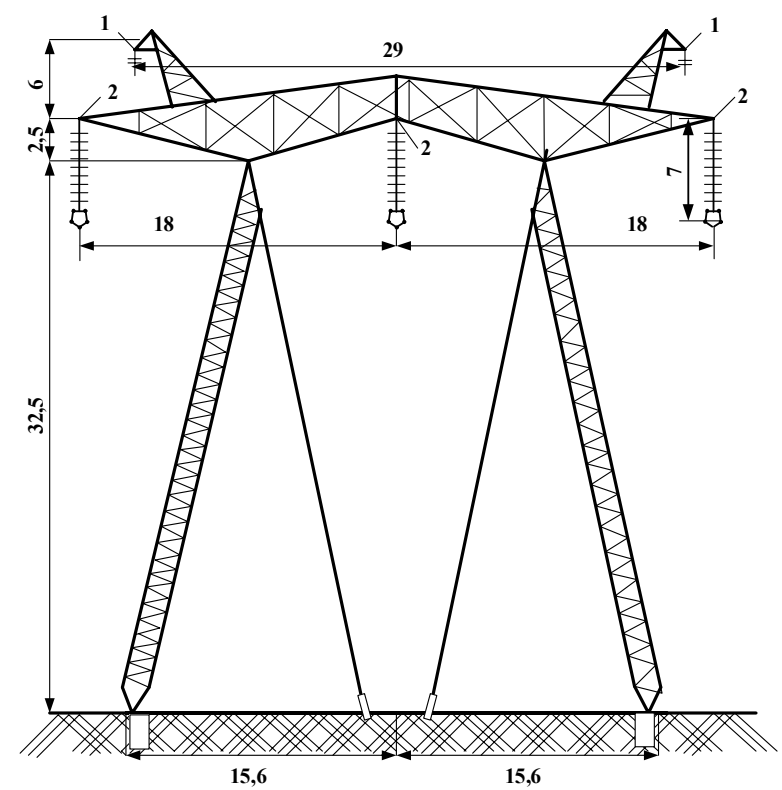

Fig. 1

Line inductance in straight sequence:

$$
L_{1}=\frac{0,145}{\omega} \lg \left(\frac{D_{a v}}{\rho_{\text {eq.w }}}\right),
$$

where $D_{a v}=\sqrt[3]{D_{A B} D_{B C} D_{C A}}$ - average geometric distance between phases; $\rho_{\text {eq.w }}=\sqrt[5]{\sqrt{2} \cdot 0,9 \cdot \rho_{w} \cdot a^{3}}-$ equivalent wire radius when splitting the phase into five conductors; $a$ - the distance between split conductors in the phase; $\rho_{w}$ - the radius of one split conductor.

Zero sequence inductance:

$$
L_{0}=\frac{j 0,435}{\omega} \lg \left(\frac{D_{E}}{\rho_{a v}}\right)
$$

where $\rho_{a v}=\sqrt[5]{\rho_{\text {eq.w }} D_{a v}^{2}}$ - average geometric radius of phase; $D_{E}=\frac{66,4}{\sqrt{f \lambda}}-$ depth of stratification in the ground of conditional return wire. It is usually accepted for normal conditions $D_{E}=940$.

Capacity for direct and zero sequences:

$$
\begin{gathered}
C_{1}=j 0,0241 \cdot 10^{-6} / \lg \left(\frac{D_{a v}}{\rho_{\text {eq.w }}}\right) ; \\
C_{0}=0,803 \cdot 10^{-8} / \lg \left(\frac{S_{a v}}{\sqrt[3]{\rho_{\text {eq.w }} D_{a v}^{2}}}\right),
\end{gathered}
$$

where $S_{a v}=\frac{2\left(h_{a}+h_{b}+h_{c}\right)}{3}-$ average geometric distance between wires and their mirror image; $h_{a}, h_{b}, h_{c}$ - distance between phases and earth, taking into account sagging.

As it is known, lightning protection cables are used on the EHV lines, which are used to prevent the direct lightning strike. The presence of lightning protection cables affects primarily the size of capacities in a direct and zero sequences. Under the conditions of exploitation of EHV transmission lines, there are three possible ways to carry out cables: insulated, ground ropes and the 
absence of lightning protection cables. It is shown in [7] that the absence of lightning protection cables and their isolated execution has the same effect on the values of capacities and overvoltage values, therefore, two modes are considered in this work: grounding of lightning protection cables and the assumption that they are absent.

As can be seen from the formulas (1)...(4), the distance between the splitting step of phase wires is influenced more by the values of the parameters of the line $a$ and the mean geometric distance between the phases of the line $D_{a v}$. These parameters are determined by the design features of the phase line. To determine the degree of influence of the design features of the phase on the magnitude $L_{1}, L_{0}, C_{1}, C_{0}$, values $a$ and $D_{a v}$ are changing according to data ranges: $a \in[0,4 ; 0,7]$ and $D_{a v} \in[12 ; 25]$. The resulting graphs are shown on Fig. 2 for inductances.

On Fig. 2 is shown dependency of the line parameters that are widely varied. Change the geometric distance $D_{a v}$ between phases of the wire according to a constructively possible range leads to variation in the inductance and capacitance:
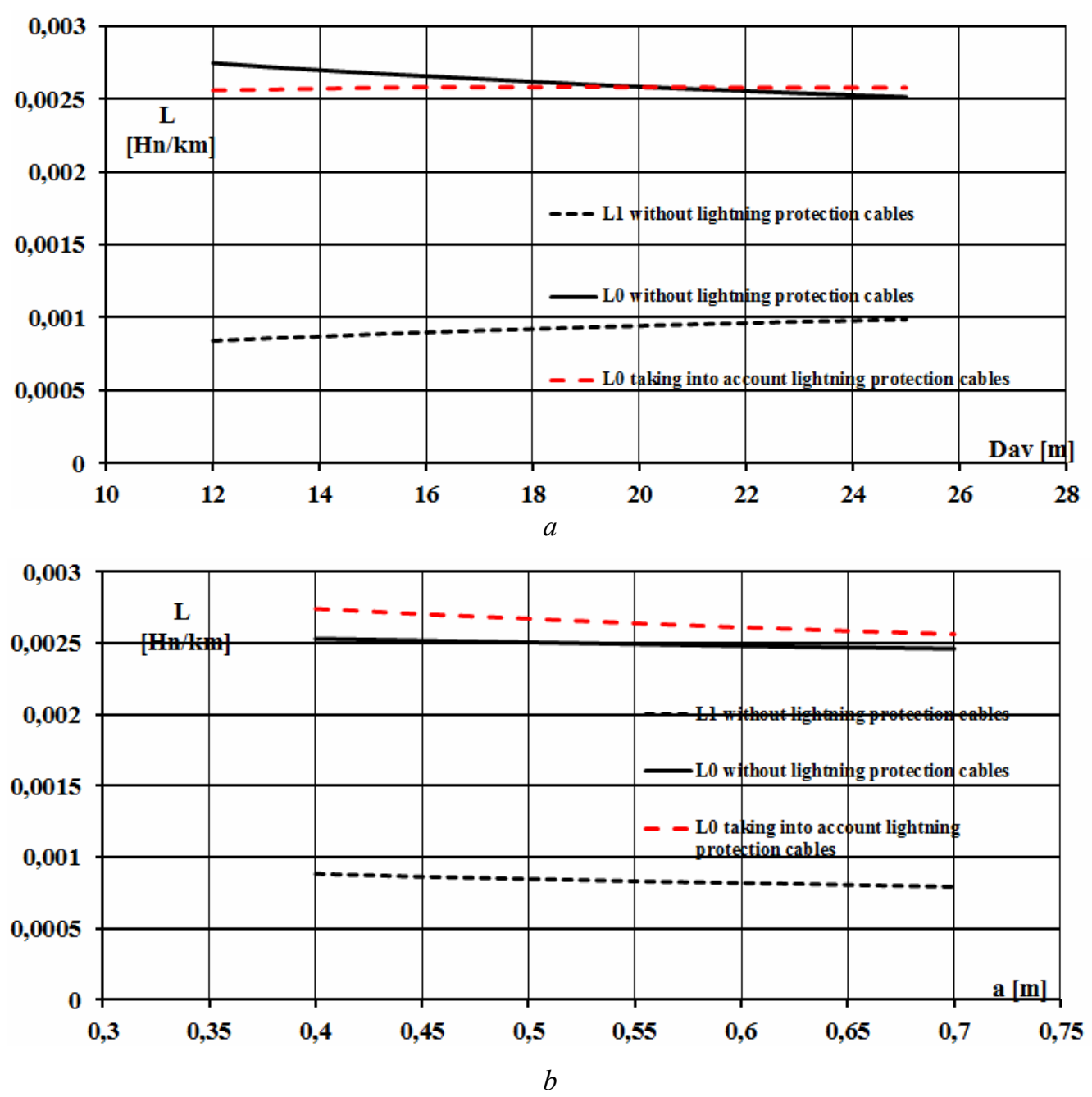

Fig. 2

The graph of change capacitences depending on the phase splitting $a$ is shown on Fig. 3 a. Accordingly, the graph of change capacitences depending on the avarage distance of the $D_{a v}$ is shown on Fig. 3 b.

On Fig. 4 depictated imitation model of connection EHV line $750 \mathrm{kV}$ to unloaded autotransformer which is energized on a $750 \mathrm{kV}$ network. The autotransformer rated $450 \mathrm{MVA}, 750$ $\mathrm{kV} / 330 \mathrm{kV} / 15,75 \mathrm{kV}$ consists of three windings connected in $\mathrm{Y} / \mathrm{Y} /$ Delta. 

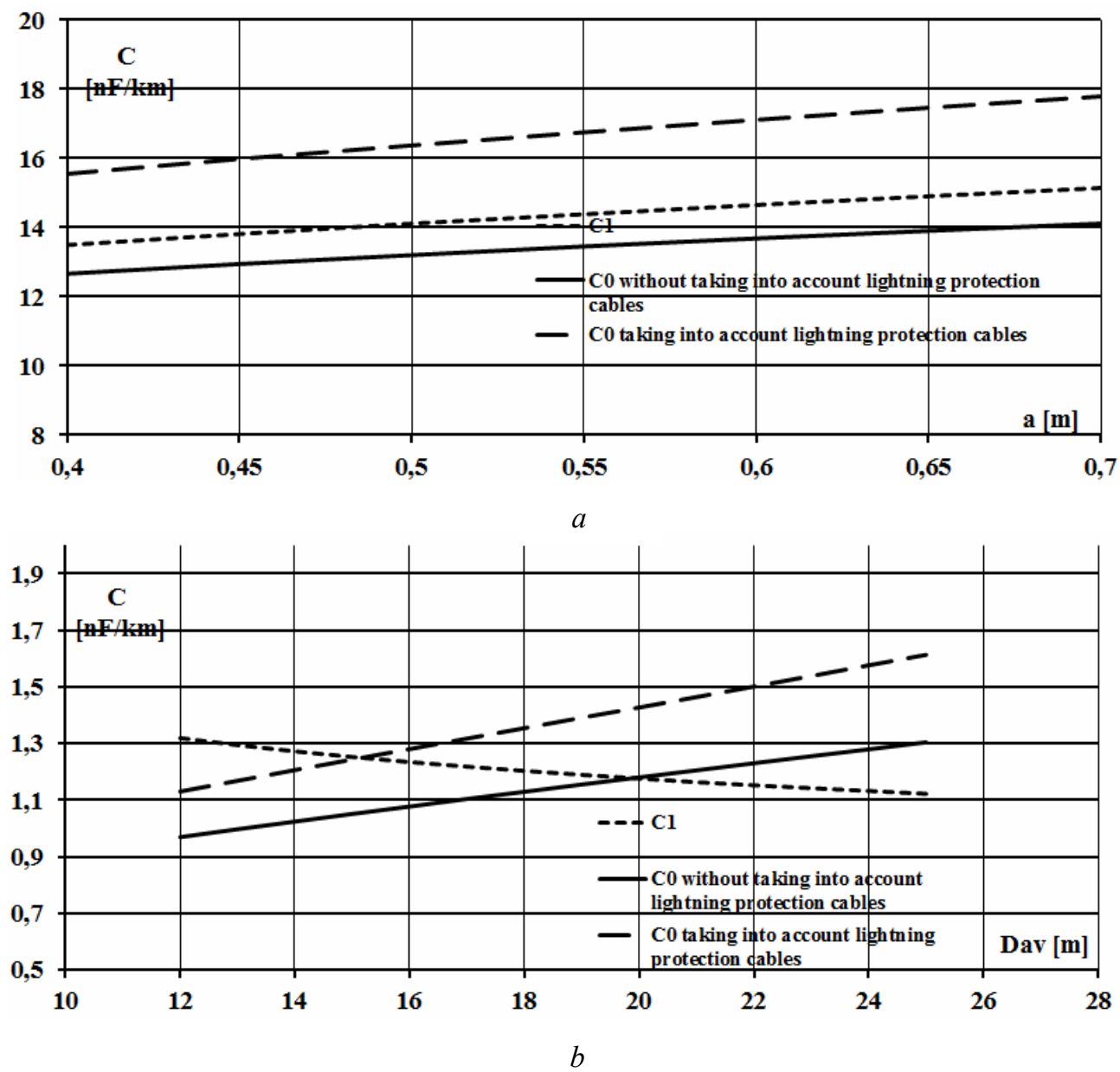

Fig. 3

The power system is simulated by an equivalent circuit consisting of an inductive source (short-circuit power of $3000 \mathrm{MVA}$ ) and a parallel $R C$ load. The autotransformer saturation characteristics is approximated by a single slope $X_{\text {sat }}=0,32 \mathrm{pu}$, corresponding to an air core reactance $X_{A C}=0,4 \mathrm{pu}$. Three residual fluxes $(-0,8 ;-0,4 ; 0,4 \mathrm{pu})$ are specified for phases A, B and $\mathrm{C}$ accordingly.

The Multimeter and Scope2 blocks are used to monitor extra signals without using measurement blocks. The six signals obtained at the output of the Multimeter are the three currents

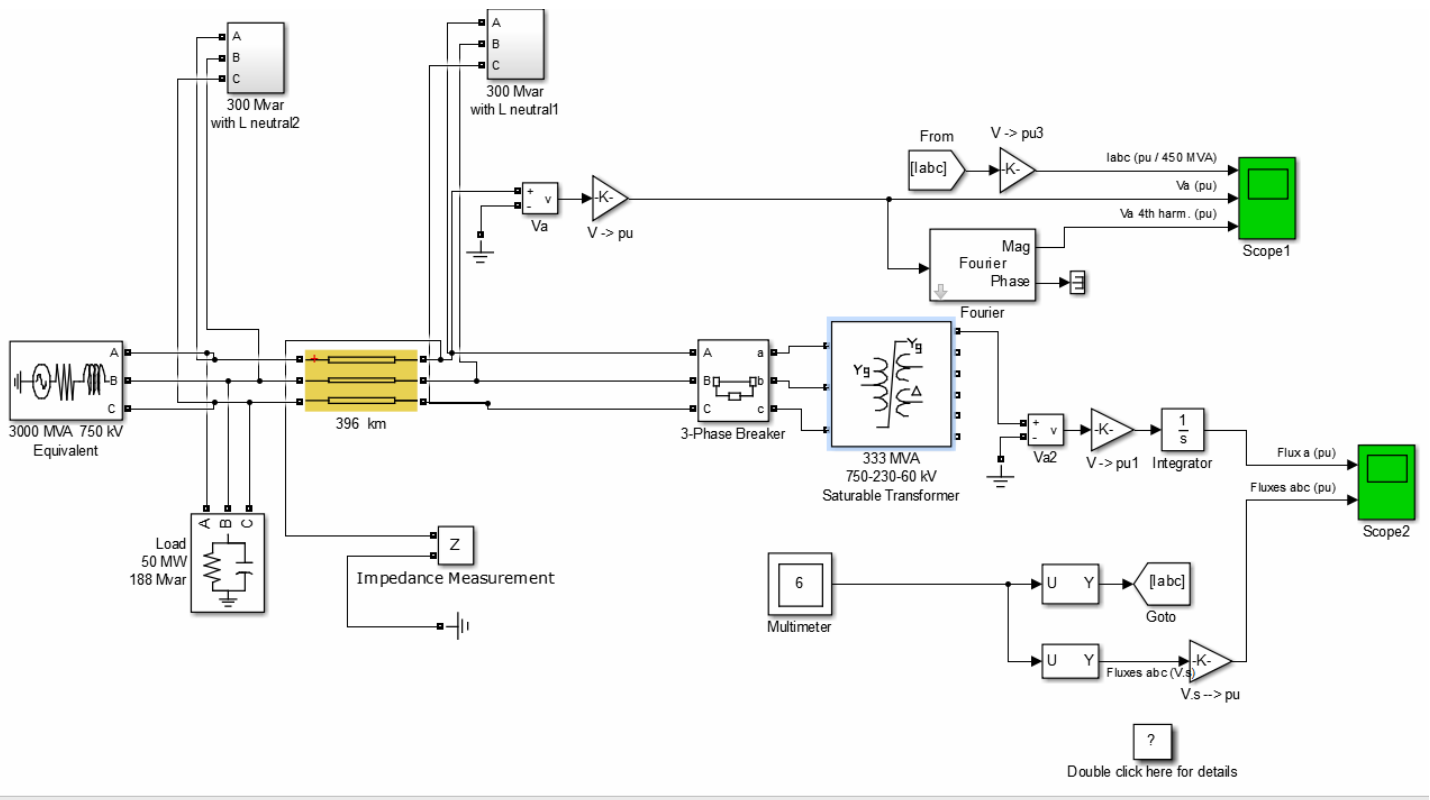




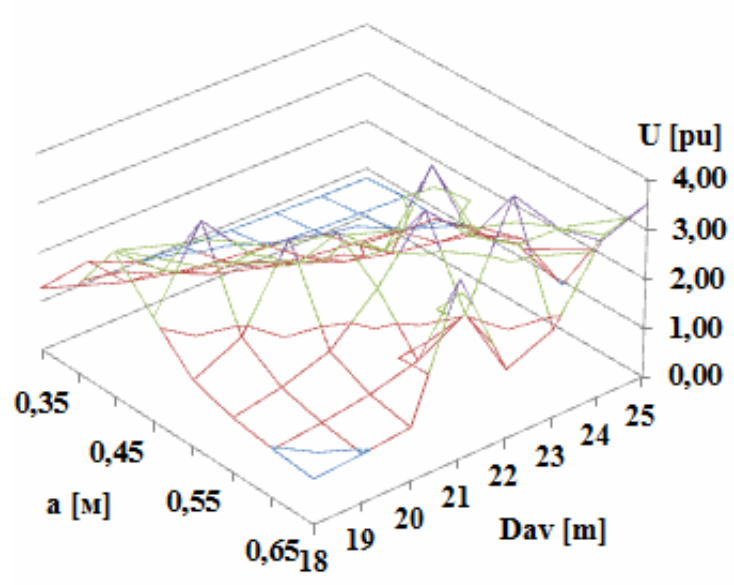

Fig. 5

in the circuit breaker and the three fluxes inside the core of the unloaded autotransformer. The flux on phase $\mathrm{A}$ is also obtained by integrating the phase $\mathrm{A}$ voltage at the unloaded output of winding two. The voltage and flux are converted to $\mathrm{pu}$ with gain blocks using proper scaling. The Fourier block measures the harmonic content of the primary voltage phase A.

Due to the developed model, the influence degree of the design features phase on the value of abnormal resonant overvoltages in the nonsinusoidal mode is determined. On fig. 5 shown a $3 \mathrm{D}$ graph of the change the value of overvoltage on $a$ and $D_{a v}$. As can be seen from Fig. 5, there are certain ranges of values at which overvoltages do not arise even at the worst conditions - the overvoltage zone of switching angle.

The following values for the splitting step and the distance between the phases are:

$$
a \in[0,4 ; 0,45] \cup \mathrm{D}_{a v} \in[20 ; 23] .
$$

As can be seen on Fig. 1 and above text the $a=0,6$ metres and the distance between outer and middle phase is 18 metres. Really existing values of $a$ and $D_{a v}$ don't fall into the within the specified range (5). Accordingly, the indicated ranges of values (5) can be recommended at the stage of designing of new extra-high voltages transmission lines.

1. In the paper one of the main sources of nonlinearity distortion is considered in the case when the unloaded autotransformer is turned on. Such a regime causes conditions for the appearance of overvoltages on the harmonics of even multiplicity. It should be noted that the process of occurrence overvoltages on the even harmonics has the specific significance of the characteristics of the abnormal resonance overvoltages and depends on many factors, especially parametres of phase construction. Therefore, the task was to develop method for determining the key factors and factors for verifying the design and operation of a superstructure network for the possibility of the emergence necessary and sufficient conditions for the existence of abnormal overvoltages.

2. Overvoltages occurring in the non-sinusoidal mode depend on the parameters of the EHV transmission lines: interphase capacity, capacitance relative to the earth, inductance of the transmission lines. Resonance arises in a circle that is powered by a nonlinear element - the magnetization shunt of autotransformer, which can cause the abnormal resonance overvoltages unpredictably. Also there is correlation between listed below parametres. Therefore, for the study of abnormal resonance overvoltages proposed, developed and used the imitational model.

1. Souza J. R. M. S., Pereira Filho C. S., De Conti A., Evaluation of the Effect of Parameters of Three-Phase Transformer Core Models on the Harmonic Content of Inrush Currents: Implications on the Setting of Inrush Detection Functions, IPST'15, Cavtat, Croatia, June, 2015.

2. Bratslavsky S. Kh., A.I. Gershengorn., S.B. Losev. Special calculations of extra-high voltage power transmission lines. Moskva: Energoatomizdat, 1985. 312 p. (Rus)

3. Chiesa N., Mork B.A., Høidalen H.K. Transformer Model for Inrush Current Calculations: Simulations, Measurements and Sensitivity Analysis, IEEE Transactions on Power Delivery. October 2010. Vol. 25 , No 4.

4. Bojić S., Electromagnetic Transients Caused by Switching Small Inductive and Capacitive Currents in High Voltage Switchyards, Ph.D. dissertation, Faculty of electrical engineering and computing, University of Zagreb, Zagreb, Croatia, 2015. 154 p.

5. Resonance and Ferroresonance in Power Networks, CIGRE WG C4.307, TB 567,2014.

6. Kuchanskyi V.V. The application of controlled switching device for prevention resonance overvoltages in nonsinusoidal modes. Proc. 37th IEEE International Conference on Electronics and Nanotechnology (ELNANO 2017), Ukraine, Kiyv, 17-19 April 2017. Pp. 394-399. 
7. Girgis R. S., teNyenhius E. G., Characteristic of Inrush Current of Present Designs of Power Transformers, Proc. IEEE Power and Energy Society General Meeting, Tampa, USA, June, 2007.

8. Kuchanskyi V.V. Controlled switching of circuit breakers in main power electrical networks. Pratsi Instytutu elektrodynamiky Natsionalnoi Akademii Nauk Ukrainy 2017. No 48. P. 38-43.

9. Libkind M.S. Higher harmonics generated by transformers. Moskva: Publishing house of the academy of sciences of the USSR, 1962. P. 104.

10. Tugay Y.I. The resonance overvoltages in EHV network. IEEE International Conference on Electrical Power Quality and Utilization. 2009. Lodz. Iss. 1. Pp. 14-18.

\section{УДК 621.315 .1}

В.В. Кучанський, канд. техн. наук Інститут електродинаміки НАН України, пр. Перемоги, 56, Київ-57, 03057, Україна

\section{ОЦІНКА ВПЛИВУ КОНСТРУКЦЇ̈ ФАЗИ ЛІНЇ̈ ЕЛЕКТРОПЕРЕДАЧІ НАДВИСОКОӤ НАПРУГИ НА} АНОРМАЛЬНІ РЕЗОНАНСНІ ПЕРЕНАПРУГИ

Мета виконаних досліджень - аналіз факторів, які призводять до виникнення в лініях електропередачі надвисокої напруги анормальних режимів, щчо супроводжуються перенапругами на вищих гармонічних складових. Враховано ступінь впливу кроку розщеплення проводів та середньогеометричної відстані між фазами на значення анормальних резонасних перенапруг у несинусоїдальних режимах роботи ліній електропередачі надвисокої напруги. Показано, щзо аномальні резонансні перенапруги такого типу є наслідком дії несинусоїдальності на параметри режиму і можуть тривати порівняно довго. Цим вони відрізняються від перенапруг, які виникають у результаті комутачій за нормальної схеми електричної мережі без джерел спотворень. Джерелом парних гармонічних складових є ненавантажений автотрансформатор, робоча точка якого знаходиться на нелінійній частині характеристики намагнічування. Розроблено імітаційну модель для оцінки можливої кратності перенапруг у несинусоїдому режимі. За допомогою імітаційного моделювання очінено вплив конструкції фази лінії електропередачі $750 \kappa B$ на виникнення пошкоджень перенапруг. Визначено значення параметрів лініі, за яких характеристики перенапруг досягають максимальних значень. Під час проектування лінії електропередачі надвисокої напруги необхідн враховувати конструкиії фази з метою запобігання виникненню анормальних резонансних перенапруг. Бібл. 10, рис. 5.

Ключові слова: лінії надвисокої напруги, анормальні резонансні перенапруги, імітаційне моделювання, несинусоїдальний режим, ненавантажений автотрансформатор.

В.В. Кучанский, канд. техн. наук

Институт электродинамики НАН Украины,

пр. Победы, 56, Киев-57, 03057, Украина

\section{ОЦЕНКА ВЛИЯНИЯ КОНСТРУКЦИИ ФАЗЫ ЛИНИИ ЭЛЕКТРОПЕРЕДАЧИ СВЕРХВЫСОКОГО} НАПРЯЖЕНИЯ НА АНОРМАЛЬНЫЕ РЕЗОНАНСНЫЕ ПЕРЕНАПРЯЖЕНИЯ

Анормальный несинусоидальный режим характеризуется появлением высших гармоник тока и напряжения. Искажение формы кривой напряжения и токов в этом случае обусловлено нелинейностью шунта намагничивания ненагруженного автотрансформатора. В последнее время большое внимание уделяется изучению режимов работь магистральных электрических сетей с несинусоидальными источниками искажений. Причиной этого является появление анормальных резонасных режимов на линиях сверхвысокого напряжения (СВН), таких как резонансные прочессы на частотах, отличных от основной. Уделено внимание возникновению перенапряжений даже на гармонических компонентах, вызванных соединением разгруженных автотрансформаторов. Основная иель исследования - проанализировать факторы, которые приводят к возникновению анормального режима в линиях электропередачи сверхвысокого напряжения $u$ сопровождаются перенапряжениями на высших гармонических составляющих. Показано, что анормальные резонасные перенапряжения этого типа возникают как следствие действия несинусоидального режима. Учтена степень влияния шага расщепления проводов и геометрического расстояния между фазами на значения анормальных перенапряжений в несинусоидальных режимах работь линий электропередач сверхвысокого напряжения. Ненагруженный автотрансформатор является источником возникновения четных гармонических составляющих, поскольку рабочая точка находится в нелинейной части характеристики намагничивания. Разработана имитационная модель для проверки возможного возникновения перенапряжений в рассматриваемом несинусоидальном режиме. Численное моделирование электромагнитных коммутационных процессов на имитационной модели использовалось для выявления факторов, которые оказывают наибольшее влияние на возникновение анормальных перенапряжений, прежде всего конструктивных особенностей исполнения линии электропередачи. Найдень критические значения параметров линии, в которых повышается перенапряжение до максимального значения. Библ. 10, рис. 5.

Ключевые слова: линии сверхвысокого напряжения, анормальные резонансные перенапряжения, имитационное моделирование, несинусоидальный режим, ненагруженный автотрансформатор. 